\title{
Room Temperature Ionic Liquid Electrolytes for Redox Flow Batteries
}

\author{
Andinet Ejigu, Peter Greatorex-Davies and Darren A. Walsh* \\ School of Chemistry, The University of Nottingham, Nottingham NG7 2RD, UK \\ *darren.walsh@nottingham.ac.uk;
}

Tel: 0044115 8467495; Fax: 00441159513562

\begin{abstract}
Redox flow batteries (RFBs) usually contain aqueous or organic electrolytes. The aim of this communication is to explore the suitability of room temperature ionic liquids (RTILs) as solvents for RFBs containing metal complexes. Towards this aim, the electrochemistry of the metal acetylacetonate (acac) complexes $\mathrm{Mn}(\mathrm{acac})_{3}, \mathrm{Cr}(\mathrm{acac})_{3}$, and $\mathrm{V}(\mathrm{acac})_{3}$ was studied in imidazolium-based RTILs. The $\mathrm{V}^{2+/} \mathrm{V}^{3+}, \mathrm{V}^{3+} / \mathrm{V}^{4+}$, and $\mathrm{V}^{4+} / \mathrm{V}^{5+}$ redox couples are quasireversible in 1-ethyl-3-methylimidazolium bis(trifluoromethanesulfonyl)imide, $\left[\mathrm{C}_{2} \mathrm{C}_{1} \operatorname{Im}\right]\left[\mathrm{N}\left(\mathrm{Tf}_{2}\right)\right]$. The $\mathrm{Mn}(\mathrm{acac})_{3}$ and $\mathrm{Cr}(\mathrm{acac})_{3}$ voltammetry, on the other hand, is irreversible in $\left[\mathrm{C}_{2} \mathrm{C}_{1} \mathrm{Im}\right]\left[\mathrm{N}\left(\mathrm{Tf}_{2}\right)\right]$ at glassy carbon $(\mathrm{GC})$ but the rate of the $\mathrm{Mn}^{2+} / \mathrm{Mn}^{3+}$ reaction increases if $\mathrm{Au}$ electrodes are used. Charge-discharge measurements show that a coulombic efficiency of $72 \%$ is achievable using a $\mathrm{V}(\mathrm{acac})_{3} /\left[\mathrm{C}_{2} \mathrm{C}_{1} \mathrm{Im}\right]\left[\mathrm{N}\left(\mathrm{Tf}_{2}\right)\right] / \mathrm{GC}$ cell.
\end{abstract}

Keywords: Ionic Liquids; Energy Storage; Cyclic Voltammetry; Electrochemical Impedance Spectroscopy; Redox Flow Battery 


\section{Introduction}

Electrochemical devices that store energy generated by sources such as solar panels and wind turbines are expected to play crucial roles in the future. RFBs are currently attracting particular attention due to their simplicity and ability to store large amounts of energy [1,2]. In RFBs, dissolved redox species are stored in tanks and pumped to an electrochemical cell during discharging and charging. During discharge, the redox species are reduced and oxidized at the positive and negative electrode, respectively, resulting in the flow of current between the electrodes. During charging, an electrical current is used to drive the reactions in the opposite direction.

While most RFBs contain aqueous electrolytes (common systems include the allvanadium, bromine-polysulfide, and zinc-bromine systems [2]), their energy and power densities are limited as they must operate within the potential region where water is stable $(<1.23 \mathrm{~V})[3]$. Organic electrolytes often have wider potential windows than that of water and, consequently, there is a lot of interest in high energy density, organic RFB systems and systems based on $\mathrm{Ru}$ [4], $\mathrm{V}$ [5], Mn [6], and $\mathrm{Cr}$ [7] complexes have been reported. In a similar approach to that used in the popular aqueous all-vanadium RFBs [8], the same chemical species is often used on each side of non-aqueous RFBs, mitigating the effects of transfer of redox species between compartments and increasing the coulombic efficiency [3].

Despite the advantages offered by organic solvents to RFBs, solvent flammability and evaporative losses could hinder uptake of such cells. A possible solution is to use an RTIL as solvent; due to their thermal and electrochemical stability, low vapour pressures, and wide potential windows, RTILs are being used in electrochemical devices such as batteries, supercapacitors, and fuel cells but relatively few studies have explored their use in RFBs [911]. A couple of studies involved using RTILs as supporting electrolytes in non-aqueous, all- 
vanadium RFBs with the aim of optimising electrolyte compositions [12,13]. Chakrabarti et al. studied several metal acac salts (with a view to use in RFBs) at GC electrodes in deep eutectic solvents (a sub-class of RTILs) but solubilities were low and a functioning cell containing the electrolytes was not demonstrated [14]. Tsuda et al. developed a cell containing $\mathrm{AlBr}_{3}$ and $\left[\mathrm{C}_{2} \mathrm{C}_{1} \mathrm{Im}\right] \mathrm{Br}$, in which $\mathrm{Al}$ is electrodeposited at the negative electrode [15]. Recently, Teramoto et al. described the electrochemical behaviour of several Fe(II) complexes in 1-butyl-3-methylimidazolium bis(trifluoromethanesulfonyl)imide $\left[\mathrm{C}_{4} \mathrm{C}_{1} \mathrm{Im}\right]\left[\mathrm{N}\left(\mathrm{Tf}_{2}\right)\right]$, with the aim of using this mediator as an electrolyte in RFBs [16]. Oxidation and reduction peaks associated with the $\mathrm{Fe}^{2+/ 3+}$ redox couple were observed and the reaction was electrochemically quasi-reversible. To the best of our knowledge, and despite the opportunities offered both by pure RTIL electrolytes and metal acac salts to RFB technology, RFBs based on soluble $\mathrm{V}(\text { acac })_{3}, \mathrm{Mn}(\mathrm{acac})_{3}$ and $\mathrm{Cr}(\mathrm{acac})_{3}$ (which are very promising for use on organic solvent-based cells [3]) and pure RTIL solvents have not been reported.

We describe here an investigation of the electrochemistry of $\mathrm{Mn}(\mathrm{acac})_{3}, \mathrm{Cr}(\mathrm{acac})_{3}$, and $\mathrm{V}(\mathrm{acac})_{3}$ in RTILs. Using a series of aprotic imidazolium-based RTILs, we demonstrate significant differences in the voltammetry of $\mathrm{V}(\mathrm{acac})_{3}, \mathrm{Cr}(\mathrm{acac})_{3}$ and $\mathrm{Mn}(\mathrm{acac})_{3}$. Furthermore, we show that $\mathrm{V}(\mathrm{acac})_{3}$ oxidation/reduction in $\left[\mathrm{C}_{2} \mathrm{C}_{1} \operatorname{Im}\right]\left[\mathrm{N}\left(\mathrm{Tf}_{2}\right)\right]$ is electrochemically quasi-reversible and we describe a simple 2-electrode cell containing $\mathrm{V}(\mathrm{acac})_{3},\left[\mathrm{C}_{2} \mathrm{C}_{1} \operatorname{Im}\right]\left[\mathrm{N}\left(\mathrm{Tf}_{2}\right)\right]$ and $\mathrm{GC}$ electrodes, which exhibits a high columbic efficiency. Finally, we briefly discuss the prospects for the use of RTILs in fully-functional RFBs. 


\section{Experimental Section}

RTILs were prepared according to published procedures [17]. Measurements were performed using a model $760 \mathrm{C}$ potentiostat (CH Instruments, Austin, TX). 3-electrode cell measurements were made using an $\mathrm{Au}, \mathrm{Pt}$, or $\mathrm{GC}$ disk working electrode, Pt flag counter electrode, and $\mathrm{Ag} / \mathrm{Ag}^{+}$reference electrode, which consisted of an $\mathrm{Ag}$ wire immersed in 10 $\mathrm{mM}$ Ag triflate in $\left[\mathrm{C}_{2} \mathrm{C}_{1} \mathrm{Im}\right]\left[\mathrm{N}\left(\mathrm{Tf}_{2}\right)\right]$. Prior to use, working electrodes were polished using an aqueous suspension of $0.05 \mu \mathrm{m}$ alumina, rinsed thoroughly with deionized water, and dried in air. Charge-discharge curves were recorded using a H-type cell containing two 3-mm diameter GC disk electrodes separated by a porous glass frit at charge/discharge currents of $0.02 \mathrm{~mA} \mathrm{~cm}{ }^{-2}$ with $0.0 \mathrm{~V}$ and $2.5 \mathrm{~V}$ potential cutoffs. Electrochemical impedance spectroscopy (EIS) was performed in the range $100 \mathrm{kHz}-100 \mathrm{mHz}$ at an applied potential of $-0.1 \mathrm{~V}$ and an oscillation amplitude of $5 \mathrm{mV}$. Impedance spectra were fitted to an appropriate model using Z-view software (Scribner Associates Inc.).

\section{Results and Discussion}

\subsection{Electrochemistry of V(acac $)_{3}$ in RTILs}

Figure 1A shows a cyclic voltammograms $(\mathrm{CV})$ recorded at $\mathrm{GC}$ in $\mathrm{V}(\mathrm{acac})_{3}$ in $\left[\mathrm{C}_{2} \mathrm{C}_{1} \mathrm{Im}\right]\left[\mathrm{N}\left(\mathrm{Tf}_{2}\right)\right]$. Three well-defined redox couples centred at $-1.37,0.63$, and $0.90 \mathrm{~V}$ are visible. Similar responses have been observed in organic solvents and the couples are the $\mathrm{V}^{2+} / \mathrm{V}^{3+}, \mathrm{V}^{3+} / \mathrm{V}^{4+}$, and $\mathrm{V}^{4+} / \mathrm{V}^{5+}$ couples, respectively [5,18]. The potential difference, $\Delta E$, between the $\mathrm{V}^{2+} / \mathrm{V}^{3+}$ and $\mathrm{V}^{3+} / \mathrm{V}^{4+}$ couples is $2.0 \mathrm{~V}$, which compares to values of $2.2 \mathrm{~V}$ in acetontrile [5] and 2.61 V, 2.58 V, 2.31 V, and 2.21 V in tetrahydrofuran, 1,3-dioxolane, 
acetylacetone and dimethyl sulfoxide, respectively [18]. Such a decrease in $\Delta E$ for consecutive redox waves upon changing solvents from acetonitrile to RTILs (due to an increase in the Lewis basicity of the solvent) has been observed previously during voltammetry of the 2,2-diphenyl-1-picrylhydrazyl (DPPH) radical [19] so it appears that the RTIL is more basic than each of these solvents (the voltammetry of $\mathrm{Mn}(\mathrm{acac})_{3}$ is similarly affected - Section 3.2). Measurement of Lewis basicities (and Gutmann donor numbers) of RTILs is an active, if controversial, area of research [20-22] and this observation suggests that the voltammetry of acac complexes could potentially be used to rank RTILs in order of basicity, as has been done using DPPH [19].

Figure $1 \mathrm{~B}$ and $1 \mathrm{C}$ show that the $\mathrm{V}(\mathrm{acac})_{3}$ redox couples were not clearly discernable in $\left[\mathrm{C}_{4} \mathrm{C}_{1} \operatorname{Im}\right]\left[\mathrm{BF}_{4}\right]$ and $\left[\mathrm{C}_{4} \mathrm{C}_{1} \mathrm{Im}\right]\left[\mathrm{PF}_{6}\right]\left(\left[\mathrm{C}_{4} \mathrm{C}_{1} \mathrm{Im}\right]^{+}\right.$is the 1-butyl-3-methylimidazolium cation $)$. In $\left[\mathrm{C}_{2} \mathrm{C}_{1} \mathrm{Im}\right]\left[\mathrm{N}(\mathrm{CN})_{2}\right]$ and $\left[\mathrm{C}_{2} \mathrm{C}_{1} \operatorname{Im}\right]\left[\mathrm{EtSO}_{4}\right]\left(\left[\mathrm{EtSO}_{4}\right]^{-}\right.$is the ethylsulfate anion), the redox couple at positive potentials was chemically irreversible (Figures $1 \mathrm{D}$ and $1 \mathrm{E}$ ). In the particular case of $\left[\mathrm{C}_{2} \mathrm{C}_{1} \mathrm{Im}\right]\left[\mathrm{N}(\mathrm{CN})_{2}\right]$, a cathodic, return peak did appear as the scan rate, $v$, increased and the ratio of the the cathodic to anodic peak currents, $i_{\mathrm{p}, \mathrm{c}}: i_{\mathrm{p}, \mathrm{c}}$ increased to 0.6 at 1 $\mathrm{V} \mathrm{s}^{-1}$, suggesting that a following chemical reaction occurred after oxidation [23]. Additional waves appeared at negative potentials in $\operatorname{In}\left[\mathrm{C}_{2} \mathrm{C}_{1} \operatorname{Im}\right]\left[\mathrm{N}(\mathrm{CN})_{2}\right]$ and $\left[\mathrm{C}_{2} \mathrm{C}_{1} \operatorname{Im}\right]\left[\mathrm{EtSO}_{4}\right]$ and a complete assignment of the waves in these RTILs is, as yet, difficult. However, we can say that, of the RTILs studied, only $\left[\mathrm{C}_{2} \mathrm{C}_{1} \operatorname{Im}\right]\left[\mathrm{N}\left(\mathrm{Tf}_{2}\right)\right]$ stabilizes the various $\mathrm{V}^{n+}$ species. It is also important to note that the use of $\left[\mathrm{C}_{4} \mathrm{C}_{1} \mathrm{Im}\right]\left[\mathrm{N}\left(\mathrm{Tf}_{2}\right)\right]$ yields almost identical voltammetry (not shown) to that observed in $\left[\mathrm{C}_{2} \mathrm{C}_{1} \operatorname{Im}\right]\left[\mathrm{N}\left(\mathrm{Tf}_{2}\right)\right]$. Therefore, it appears that the RTILs anions play the most significant roles in stabilizing the $\mathrm{V}^{n+}$ species. 


\subsection{Electrochemistry of $\mathrm{Cr}(\text { acac })_{3}$ and $\mathrm{Mn}(\operatorname{acac})_{3}$ in RTILs}

As $\left[\mathrm{C}_{2} \mathrm{C}_{1} \mathrm{Im}\right]\left[\mathrm{N}\left(\mathrm{Tf}_{2}\right)\right]$ was a good RTIL for $\mathrm{V}(\mathrm{acac})_{3}$ voltammetry, CVs were recorded in $\left[\mathrm{C}_{2} \mathrm{C}_{1} \mathrm{Im}\right]\left[\mathrm{N}\left(\mathrm{Tf}_{2}\right)\right]$ containing $\mathrm{Cr}(\mathrm{acac})_{3}$ and $\mathrm{Mn}(\mathrm{acac})_{3}$. The $\mathrm{CV}$ recorded at $\mathrm{GC}$ in $\mathrm{Cr}(\mathrm{acac})_{3} /\left[\mathrm{C}_{2} \mathrm{C}_{1} \mathrm{Im}\right]\left[\mathrm{N}\left(\mathrm{Tf}_{2}\right)\right]$ (Figure $2 \mathrm{~A}$ ) shows two chemically-irreversible cathodic waves at $-1.97 \mathrm{~V}$ and $-1.85 \mathrm{~V}$ and two irreversible oxidation waves at $1.30 \mathrm{~V}$ and $1.76 \mathrm{~V}$, which we attribute to the $\mathrm{Cr}^{+} / \mathrm{Cr}^{2+}, \mathrm{Cr}^{2+} / \mathrm{Cr}^{3+}, \mathrm{Cr}^{3+} / \mathrm{Cr}^{4+}$, and $\mathrm{Cr}^{4+} / \mathrm{Cr}^{5+}$ couples, respectively [7]. It is interesting to note that the irreversibility of each couple (indeed the entire response, ignoring the fact that we cannot directly compare potentials due to the use of different reference electrodes) mirrors that recorded in acetonitrile, and may be attributable to ligand loss upon oxidation/reduction [7]. The black line in Figure 2B shows the $\mathrm{CV}$ recorded at $\mathrm{GC}$ in $\mathrm{Mn}(\mathrm{acac})_{3} /\left[\mathrm{C}_{2} \mathrm{C}_{1} \mathrm{Im}\right]\left[\mathrm{N}\left(\mathrm{Tf}_{2}\right)\right]$. In each case, two well-defined redox waves are visible, which we attribute to the $\mathrm{Mn}^{2+} / \mathrm{Mn}^{3+}\left(E^{0,}=-0.1 \mathrm{~V}\right)$ and $\mathrm{Mn}^{3+} / \mathrm{Mn}^{4+}\left(E^{0,}=0.74 \mathrm{~V}\right)$ couples. $\Delta E$ in this case $(0.84 \mathrm{~V})$ is lower than in acetonitrile $(1.1 \mathrm{~V})[6]$, in agreement with the $\mathrm{V}(\mathrm{acac})_{3}$ voltammetry described above.

At the GC electrode, the peak-to-peak separation, $\Delta E_{\mathrm{p}}$, for the $\mathrm{Mn}^{2+} / \mathrm{Mn}^{3+}$ couple was $382 \mathrm{mV}$ and, for the $\mathrm{Mn}^{3+} / \mathrm{Mn}^{4+}$ couple, was $99 \mathrm{mV}$. This behaviour is different from that observed in acetonitrile, where the redox couples show similar $\Delta E_{\mathrm{p}}$ values [6,24]. It is interesting to note that $\Delta E_{\mathrm{p}}$ for the $\mathrm{Mn}^{2+} / \mathrm{Mn}^{3+}$ couple was $589 \mathrm{mV}$ at $\mathrm{Pt}$ and $140 \mathrm{mV}$ at $\mathrm{Au}$ (Figure $2 \mathrm{~B}$ blue and red lines, respectively). The decrease in $\Delta E_{\mathrm{p}}$ in the order $\mathrm{Pt}>\mathrm{GC}>\mathrm{Au}$ indicates that electron transfer (ET) kinetics were fastest at $\mathrm{Au}$ and slowest at Pt. To further compare ET kinetics at the various electrodes, EIS was performed and Figure $2 \mathrm{C}$ shows the resulting Nyquist plots. The charge transfer resistance $\left(R_{\mathrm{CT}}\right)$ at the electrode/electrolyte interface was determined by fitting the data to the Randles equivalent circuit shown in the inset (containing a solution resistance, $R_{\mathrm{S}}$, constant phase element, $\mathrm{CPE}$, diffusion impedance, 
$W$, and $\left.R_{\mathrm{CT}}\right) . \quad R_{\mathrm{CT}}$ was $280 \Omega \mathrm{cm}^{2}, 1382 \Omega \mathrm{cm}^{2}$, and $2233 \Omega \mathrm{cm}^{2}$ at $\mathrm{Au}, \mathrm{GC}$, and $\mathrm{Pt}$, respectively, demonstrating that $\mathrm{ET}$ was fastest at $\mathrm{Au}$, in agreement the $\mathrm{CV}$ data.

\subsection{Mass and Charge Transport in the $V(\text { acac })_{3} /\left[C_{2} C_{1} I m\right]\left[N\left(T f_{2}\right)\right]$ System}

Returning to the relatively "well-behaved" $\mathrm{V}(\mathrm{acac})_{3} /\left[\mathrm{C}_{2} \mathrm{C}_{1} \mathrm{Im}\right]\left[\mathrm{N}\left(\mathrm{Tf}_{2}\right)\right]$ system, Figure $3 \mathrm{~A}$ shows CVs recorded at a range of scan rates, $v$ (focusing on the $\mathrm{V}^{3+} / \mathrm{V}^{4+}$ and $\mathrm{V}^{4+} / \mathrm{V}^{5+}$ couples). In the range $0.05 \mathrm{~V} \mathrm{~s}^{-1} \leq v \leq 1 \mathrm{~V} \mathrm{~s}^{-1}, i_{\mathrm{p}, \mathrm{a}}: i_{\mathrm{p}, \mathrm{c}}$ was close to 1 (particularly for the $\mathrm{V}^{3+} / \mathrm{V}^{4+}$ couple; $i_{\mathrm{p}, \mathrm{a}}$ for the $\mathrm{V}^{4+} / \mathrm{V}^{5+}$ couple was slightly higher than $\left.i_{\mathrm{p}, \mathrm{c}}\right)$ and $\Delta E_{\mathrm{p}}$ at $25 \mathrm{mV} \mathrm{s}^{-1}$ was $85 \mathrm{mV}$ for the $\mathrm{V}^{2+} / \mathrm{V}^{3+}$ couple (not shown), $60 \mathrm{mV}$ for the $\mathrm{V}^{3+} / \mathrm{V}^{4+}$ couple, and $66 \mathrm{mV}$ for $\mathrm{V}^{4+} / \mathrm{V}^{5+}$ couple. These values are close to the value of $59 \mathrm{mV}$ expected for an electrochemically-reversible, one-electron transfer [24] but $\Delta E_{\mathrm{p}}$ increased to 120,102 and $120 \mathrm{mV}$, respectively, as $v$ increased to $500 \mathrm{mV} \mathrm{s}^{-1}$, suggesting that ET kinetics influenced the response at higher scan rates.

Figure 3B shows a typical chronoamperogram obtained in $10 \mathrm{mM} \mathrm{V}(\mathrm{acac})_{3}$ in $\left[\mathrm{C}_{2} \mathrm{C}_{1} \mathrm{Im}\right]\left[\mathrm{N}\left(\mathrm{Tf}_{2}\right)\right]$, which was obtained by stepping the potential from one where no faradaic reaction occurred to one where the oxidation of $\mathrm{V}^{3+}$ to $\mathrm{V}^{4+}$ was diffusion controlled. The inset of Figure 3B shows the corresponding Cottrell plot of $i v s . t^{-1 / 2}$ and, from the gradient of the best-fit straight line, the diffusion coefficient, $D$, of $\mathrm{V}^{3+}$ was determined to be $1.07 \times 10^{-7}$ $\mathrm{cm}^{2} \mathrm{~s}^{-1}$. The diffusion coefficient of $\mathrm{V}(\mathrm{acac})_{3}$ was also estimated from the $\mathrm{CV}$ data using Equation 1:

$i_{\mathrm{p}}=2.99 \times 10^{5} n^{3 / 2} \alpha^{1 / 2} A D^{1 / 2} C v^{1 / 2}$

where $n$ is the number of electrons transferred per $\mathrm{V}(\mathrm{acac})_{3}$ molecule, $\alpha$ is the transfer coefficient, $A$ is the area of the electrode and $C$ is the bulk concentration of $\mathrm{V}(\text { acac })_{3}$. Using 
Equation $1, D$ is $2.5 \times 10^{-7} \mathrm{~cm}^{2} \mathrm{~s}^{-1}$ (assuming $\alpha=0.5$ ), in reasonably good agreement with the value obtained using chronoamperometry.

The diffusion coefficients measured in $\left[\mathrm{C}_{2} \mathrm{C}_{1} \mathrm{Im}\right]\left[\mathrm{N}\left(\mathrm{Tf}_{2}\right)\right]$ are an order of magnitude lower than in acetonitrile $\left(1.8 \times 10^{-6} \mathrm{~cm}^{2} \mathrm{~s}^{-1}\right)$ [5] and such sluggish mass transport, due to the relatively high viscosity of RTILs, has been discussed in detail previously [25]. The low diffusion coefficients measured in this system suggest that RFBs containing $\left[\mathrm{C}_{2} \mathrm{C}_{1} \mathrm{Im}\right]\left[\mathrm{N}\left(\mathrm{Tf}_{2}\right)\right]$ as the electrolyte could face mass transport issues. Of course, one also has to consider that the electrolyte in an RFB is pumped to the electrolytic cell and the relatively high viscosity of many RTILs could affect pumping speeds. It may be that operation at elevated temperatures (which is possible due to the thermal stability of RTILs) could facilitate both mass and charge transport as the viscosity of RTILs is strongly temperature dependent (the viscosity of $\left[\mathrm{C}_{2} \mathrm{C}_{1} \mathrm{Im}\right]\left[\mathrm{N}\left(\mathrm{Tf}_{2}\right)\right]$ decreases from $33 \mathrm{mPa} \mathrm{s}$ to $6 \mathrm{mPa} \mathrm{s}$ as the temperature increases from $25{ }^{\circ} \mathrm{C}$ to $100{ }^{\circ} \mathrm{C}$ [26]). In addition, while all-vanadium aqueous RFBs are limited to $\leq 40{ }^{\circ} \mathrm{C}$ as precipitation of $\mathrm{V}_{2} \mathrm{O}_{5}$ occurs (Equation 2) at high temperatures [27], the redox mediator in our system is $\mathrm{V}(\mathrm{acac})_{3}$, there is no $\mathrm{VO}_{2}^{+}$present, and water is present only at trace amounts. Therefore, unlike aqueous all-vanadium RFBs, operation of $\mathrm{V}(\mathrm{acac})_{3} / \mathrm{RTIL}$ cells at high temperatures could well be possible, thereby mitigating mass transport problems. Of course, such factors require further exploration in the future.

$2 \mathrm{VO}_{2}^{+}+\mathrm{H}_{2} \mathrm{O} \rightarrow \mathrm{V}_{2} \mathrm{O}_{5}+2 \mathrm{H}^{+}$

\subsection{Charge-Discharge Analysis of $\mathrm{V}(\mathrm{acac})_{3}$ in $\left[\mathrm{C}_{2} \mathrm{C}_{1} \mathrm{Im}\right]\left[\mathrm{N}\left(\mathrm{Tf}_{2}\right)\right]$}

Figure 3C shows a charge-discharge curve recorded in a H-type cell containing 10 $\mathrm{mM} \mathrm{V}(\mathrm{acac})_{3}$ in $\left[\mathrm{C}_{2} \mathrm{C}_{1} \mathrm{Im}\right]\left[\mathrm{N}\left(\mathrm{Tf}_{2}\right)\right]\left(3^{\text {rd }}\right.$ cycle $)$. During discharge, $\mathrm{V}(\mathrm{acac})_{3}$ is oxidized to 
$\left[\mathrm{V}(\mathrm{acac})_{3}\right]^{+}$at the positive electrode and $\mathrm{V}(\mathrm{acac})_{3}$ is reduced to $\left[\mathrm{V}(\mathrm{acac})_{3}\right]^{-}$at the negative electrode, as was also the case in the acetonitrile/ $\mathrm{V}(\mathrm{acac})_{3}$ cell built by Liu et al. [5]. During charging, the potential increased rapidly from $0.0 \mathrm{~V}$ to $1.4 \mathrm{~V}$ followed by a steady increase to $\sim 2.0 \mathrm{~V}$. As the concentration of $\mathrm{V}^{3+}$ at the electrode surface dropped, the potential rose to 2.1-2.4 V. During discharge, two plateaus were observed, one at $0.75 \mathrm{~V}$ and the other at 0.5 V. The low discharge voltage may be due to ohmic effects $[5,13]$; in particular, the large separation distance between the electrodes may contribute to a high cell resistance. The columbic efficiency $\left(\eta_{\mathrm{c}}\right)$ of the cell was estimated using Equation 3:

$\eta_{c}=\frac{i_{d} t_{d}}{i_{c} t_{c}}$

where $i_{\mathrm{c}}, i_{\mathrm{d}}, t_{\mathrm{c}}, t_{\mathrm{d}}$ are charge and discharge currents and times. $\eta_{\mathrm{c}}$ was $72 \pm 3 \%$, which is comparable to that obtained using a $\mathrm{V}(\mathrm{acac})_{3}$ /acetonitrile system [18]. Voltage and energy efficiencies of $30 \%$ and $22 \%$, respectively, were also estimated form the charge-discharge curve and are comparable to those measured for the $\mathrm{V}(\mathrm{acac})_{3} / 1,3$-dioxolane system and lower than for the $\mathrm{V}(\mathrm{acac})_{3}$ /dimethyl sulfoxide system [18]. Of course, we should point out that our cell is not optimised and is rather a "proof-of-principle" device. Preliminary attempts to use the anion exchange membrane used in a number of non-aqueous RFBs (AMI-7001 from Membranes International Inc.) resulted in dissolution of the membrane when in contact with $\left[\mathrm{C}_{2} \mathrm{C}_{1} \mathrm{Im}\right]\left[\mathrm{N}\left(\mathrm{Tf}_{2}\right)\right]$, so we opted to demonstrate our system using a porous glass frit, which will have contributed to the low efficiencies due to passage of redox species between compartments. As such, if such technology is to progress, future work should focus on designing anion exchange membranes that work and are stable in RTILs.

Another factor that must be considered during optimisation of the cell is the solubility of the redox species. In our proof-of-principle experiments, we used dilute $\mathrm{V}(\mathrm{acac})_{3}$ solutions but we have measured the solubility of $\mathrm{V}(\mathrm{acac})_{3}$ in $\left[\mathrm{C}_{2} \mathrm{C}_{1} \operatorname{Im}\right]\left[\mathrm{N}\left(\mathrm{Tf}_{2}\right)\right]$ as at least 0.5 
$\mathrm{M}$, which will increase the achievable current densities in operational devices. While such a concentration greatly exceeds those achievable for similar complexes in other ionic media [14], it is important to note that the concentration of the least-soluble redox species will control the concentration of the dissolved redox species. The solubility of one or more of the other $\mathrm{V}^{n+}$ species could be lower than that of the $\mathrm{V}^{3+}$ species and such effects also require further investigation. In addition, it will be interesting to explore whether a cell can be built that initially contains different redox species $\left(e . g ., \mathrm{V}^{2+/ 3+}\right.$ and $\left.\mathrm{V}^{4+/ 5+}\right)$ as in the case of aqueous all-vanadium RFBs [2]. Such a cell would charge to a higher potential than the cell described here (due to the formation of the $\mathrm{V}^{2+}$ and $\mathrm{V}^{5+}$ species) and would discharge to a voltage higher than zero volts. It would also be interesting to determine open circuit voltages as a function of the state of charge in such systems, to compare performance data with that obtained from the more well-known, aqueous systems [2]. Of course, the performance of such cells will depend on the development of RFB membranes that can operate in RTIL environments and prevent mixing of the $\mathrm{V}^{n+}$ species between compartments, as discussed above.

In considering the feasibility of using imidazolium-based RTILs in RFBs, it is also important to consider issues such as the RTILs' stabilities and costs and the effects of contaminants such as water (a common contaminant in RTILs [28]). While RTILs such as $\left[\mathrm{C}_{2} \mathrm{C}_{1} \mathrm{Im}\right]\left[\mathrm{N}\left(\mathrm{Tf}_{2}\right)\right]$ remain relatively expensive, such costs will undoubtedly come down as the popularity of RTILs continues to grow. In addition most RTILs exhibit negligible vapour pressures and could potentially be used in an operating device for many years without any solvent loss by evaporation. In terms of the stability of $\mathrm{V}(\mathrm{acac})_{3}$ in the RTIL environment, it is known that $\mathrm{V}(\mathrm{acac})_{3}$ is susceptible to ligand-substitution in the presence of water, which yields vanadyl acetylacetonate and significantly affects the reversibility of the $\mathrm{V}^{2+} / \mathrm{V}^{3+}$ couple [29]. However, $\left[\mathrm{C}_{2} \mathrm{C}_{1} \operatorname{Im}\right]\left[\mathrm{N}\left(\mathrm{Tf}_{2}\right)\right]$ is hydrophobic and, if prepared carefully, usually contains 
ppm levels of water [26]. Moreover, no such chemical irreversibility was observed in our analysis, suggesting that such degradation mechanism may not be significant. Of course, these and other issues require attention if this technology is to progress but the data shown here suggest that the combination of $\mathrm{V}(\mathrm{acac})_{3}$ and $\left[\mathrm{C}_{2} \mathrm{C}_{1} \mathrm{Im}\right]\left[\mathrm{N}\left(\mathrm{Tf}_{2}\right)\right]$ could be very promising for use in RTIL-based RFBs.

\section{Conclusions}

The combination of $\mathrm{V}(\mathrm{acac})_{3}$ and $\left[\mathrm{C}_{2} \mathrm{C}_{1} \operatorname{Im}\right]\left[\mathrm{N}\left(\mathrm{Tf}_{2}\right)\right]$ is promising for the development of RTIL-based redox flow batteries. $\mathrm{V}(\mathrm{acac})_{3}$ oxidation/reduction in $\left[\mathrm{C}_{2} \mathrm{C}_{1} \mathrm{Im}\right]\left[\mathrm{N}\left(\mathrm{Tf}_{2}\right)\right]$ is electrochemically quasi-reversible and a simple $\mathrm{V}(\mathrm{acac})_{3} /\left(\left[\mathrm{C}_{2} \mathrm{C}_{1} \mathrm{Im}\right]\left[\mathrm{N}\left(\mathrm{Tf}_{2}\right)\right] /\right.$ glassy carbon cell with a coulombic efficiency of $72 \%$ has been built. We have also shown that oxidation/reduction of $\mathrm{Cr}(\mathrm{acac})_{3}$ and $\mathrm{Mn}(\mathrm{acac})_{3}$ is irreversible at $\mathrm{GC}$ in $\left[\mathrm{C}_{2} \mathrm{C}_{1} \mathrm{Im}\right]\left[\mathrm{N}\left(\mathrm{Tf}_{2}\right)\right]$.

While the $\mathrm{Mn}^{2+} / \mathrm{Mn}^{3+}$ redox process occurs faster at $\mathrm{Au}$ than at $\mathrm{GC}$, the use of such expensive electrode materials in RFBs would also have major cost implications. Our work has also revealed some insights into the relative Lewis basicities of $\left[\mathrm{C}_{2} \mathrm{C}_{1} \operatorname{Im}\right]\left[\mathrm{N}\left(\mathrm{Tf}_{2}\right)\right]$ and acetonitrile and suggests that $\mathrm{V}(\mathrm{acac})_{3}$ voltammetry could be used to rank RTILs in order of Lewis basicity, an important parameter for the industrial applications of RTILs. While the results described here illustrate the opportunities offered by the combination of $\mathrm{V}(\mathrm{acac})_{3}$ and $\left[\mathrm{C}_{2} \mathrm{C}_{1} \mathrm{Im}\right]\left[\mathrm{N}\left(\mathrm{Tf}_{2}\right)\right]$, optimization of the cell components and consideration of the dynamics of mass and charge transfer in RTILs at low and high temperatures must be considered if such technology is to progress and future work should focus on such issues. 


\section{Figure Legends}

Figure 1. $2^{\text {nd }}$ cycles of CVs recorded at a 5-mm diameter GC disk electrode at $50 \mathrm{mV} \mathrm{s}^{-1}$ in (A) $10 \mathrm{mM} \mathrm{V(acac})_{3}$ in $\left[\mathrm{C}_{2} \mathrm{C}_{1} \mathrm{Im}\right]\left[\mathrm{N}\left(\mathrm{Tf}_{2}\right)\right]$, (B) $11 \mathrm{mM} \mathrm{V}(\mathrm{acac})_{3}$ in $\left[\mathrm{C}_{4} \mathrm{C}_{1} \operatorname{Im}\right]\left[\mathrm{BF}_{4}\right](\mathrm{C}) 12 \mathrm{mM}$ $\mathrm{V}(\mathrm{acac})_{3}$ in $\left[\mathrm{C}_{4} \mathrm{C}_{1} \mathrm{Im}\right]\left[\mathrm{PF}_{6}\right]$, (D) $\left.12 \mathrm{mM} \mathrm{V(acac}\right)_{3}$ in $\left[\mathrm{C}_{2} \mathrm{C}_{1} \operatorname{Im}\right]\left[\mathrm{N}(\mathrm{CN})_{2}\right]$ and $(\mathrm{E}) 20 \mathrm{mM}$ $\mathrm{V}(\mathrm{acac})_{3}$ in $\left[\mathrm{C}_{2} \mathrm{C}_{1} \mathrm{Im}\right]\left[\mathrm{EtSO}_{4}\right]$. All CVs began at the negative potential limit.

Figure 2. (A) $\mathrm{CV}$ recorded at a $5-\mathrm{mm}$ diameter $\mathrm{GC}$ disk electrode at $50 \mathrm{mV} \mathrm{s}^{-1}$ in $10 \mathrm{mM}$ $\mathrm{Cr}(\mathrm{acac})_{3}$ in $\left[\mathrm{C}_{2} \mathrm{C}_{1} \mathrm{Im}\right]\left[\mathrm{N}\left(\mathrm{Tf}_{2}\right)\right]$. (B) $\mathrm{CV}$ recorded at 2-mm diameter $\mathrm{Pt}$, GC and $\mathrm{Au}$ disk electrodes at $50 \mathrm{mV} \mathrm{s}^{-1}$ in $10 \mathrm{mM} \mathrm{Mn}(\mathrm{acac})_{3}$ in $\left[\mathrm{C}_{2} \mathrm{C}_{1} \mathrm{Im}\right]\left[\mathrm{N}\left(\mathrm{Tf}_{2}\right)\right]$. All CVs began at the negative potential limit and the data shown are the $2^{\text {nd }}$ cycles. (C) Nyquist plot obtained in 10 $\mathrm{mM} \mathrm{Mn}(\mathrm{acac})_{3}$ in $\left[\mathrm{C}_{2} \mathrm{C}_{1} \mathrm{Im}\right]\left[\mathrm{N}\left(\mathrm{Tf}_{2}\right)\right]$ at 2-mm diameter Pt, GC and Au disk electrodes in a 3electrode cell in the frequency range $100 \mathrm{kHz}-100 \mathrm{mHz}$ at an applied potential of $-0.1 \mathrm{~V}$ and $5 \mathrm{mV}$ oscillation amplitude. The markers show the experimental data and the solid lines show the curves generated using the equivalent circuit shown in the inset.

Figure 3. (A) $\mathrm{CVs}$ recorded at a 5-mm diameter $\mathrm{GC}$ disk electrode in $10 \mathrm{mM} \mathrm{V}(\mathrm{acac})_{3}$ in $\left[\mathrm{C}_{2} \mathrm{C}_{1} \mathrm{Im}\right]\left[\mathrm{N}\left(\mathrm{Tf}_{2}\right)\right]$ at (from top to bottom) $1.0 \mathrm{~V} \mathrm{~s}^{-1}, 0.5 \mathrm{~V} \mathrm{~s}^{-1}, 0.2 \mathrm{~V} \mathrm{~s}^{-1}$, and $0.05 \mathrm{~V} \mathrm{~s}^{-1}$. Chronoamperogram recorded using a $5 \mathrm{~mm}$ diameter GC disk electrode in $10.0 \mathrm{mM} \mathrm{V}(\mathrm{acac})_{3}$ in $\left[\mathrm{C}_{2} \mathrm{C}_{1} \operatorname{Im}\right]\left[\mathrm{N}\left(\mathrm{Tf}_{2}\right)\right]$. The potential was stepped from $0.3 \mathrm{~V}$ to $0.7 \mathrm{~V}$ and held for $1 \mathrm{~s}$. The inset shows the plot of $i$ vs. $t^{-1 / 2}$. (C) Charge-discharge curve obtained using a H-type cell containing two $\mathrm{GC}$ (diameter $3 \mathrm{~mm}$ ) electrodes and $10 \mathrm{mM} \mathrm{V}(\mathrm{acac})_{3}$ in $\left[\mathrm{C}_{2} \mathrm{C}_{1} \operatorname{Im}\right]\left[\mathrm{N}\left(\mathrm{Tf}_{2}\right)\right]$ at charge and discharge currents of $0.02 \mathrm{~mA} \mathrm{~cm}^{-2}$. 


\section{Acknowledgements}

We thank the Leverhulme Trust for funding (Grant RPG-2010-510) and Prof. Pete Licence for providing some ionic liquids.

\section{References}

1. A.Z. Weber, M.M. Mench, J.P. Meyers, P.N. Ross, J.T. Gostick, Q.H. Liu, J. Appl. Electrochem. 2011 (41) 1137-1164.

2. C. Ponce de Leon, A. Frias-Ferrer, J. Gonzalez-Garcia, D.A. Szanto, F.C. Walsh, J. Power Sources 2006 (160) 716-732.

3. S.-H. Shin, S.-H. Yun, S.-H. Moon, RSC Adv. 2013 (3) 9095-9116. DOI: 10.1039/C3RA00115F

4. Y. Matsuda, K. Tanaka, M. Okada, Y. Takasu, M. Morita, T. Matsumura-Inoue, J. Appl. Electrochem. 1988 (18) 909-914.

5. Q. Liu, A.E.S. Sleightholme, A.A. Shinkle, Y. Li, L.T. Thompson, Electrochem. Commun. 2009 (11) 2312-2315.

6. A.E.S. Sleightholme, A.A. Shinkle, Q.H. Liu, Y.D. Li, C.W. Monroe, L.T. Thompson, J. Power Sources 2011 (196) 5742-5745.

7. Q. Liu, A.A. Shinkle, Y. Li, C.W. Monroe, L.T. Thompson, A.E.S. Sleightholme, Electrochem. Commun. 2010 (12) 1634-1637.

8. M. Rychcik, M. Skyllas-Kazacos, J. Power Sources 1988 (22) 59-67. 
9. M. Armand, F. Endres, D.R. MacFarlane, H. Ohno, B. Scrosati, Nat. Mater. 2009 (8) 621629.

10. D.R. MacFarlane, N. Tachikawa, M. Forsyth, J.M. Pringle, P.C. Howlett, G.D. Elliott, J.H. Davis, M. Watanabe, P. Simon, C.A. Angell, Energy Environ. Sci. 2014 (7) 232-250. DOI: $10.1039 / \mathrm{C} 3 \mathrm{EE} 42099 \mathrm{~J}$

11. M.H. Chakrabarti, F.S. Mjalli, I.M. AlNashef, M.A. Hashim, M.A. Hussain, L. Bahadori, C.T.J. Low, Renew. Sust. Energy Rev. 2014 (30) 254-270.

12. A.A. Shinkle, T.J. Pomaville, A.E.S. Sleightholme, L.T. Thompson, C.W. Monroe, J. Power Sources 2014 (248) 1299-1305.

13. D.P. Zhang, Q.H. Liu, X.S. Shi, Y.D. Li, J. Power Sources 2012 (203) 201-205.

14. M.H. Chakrabarti, N.P. Brandon, F.S. Mjalli, L. Bahadori, I.M. Al Nashef, M.A. Hashim, M.A. Hussain, C.T.J. Low, V. Yufit, J. Solution Chem. 2013 (42) 2329-2341.

15. T. Tsuda, I. Kokubo, M. Kawabata, M. Yamagata, M. Ishikawa, S. Kusumoto, A. Imanishi, S. Kuwabata, J. Electrochem. Soc. 2014 (161) A908-A914.

16. K. Teramoto, T. Nishide, S. Okumura, K. Takao, Y. Ikeda, Electrochemistry 2014 (82) $566-572$.

17. P. Bonhôte, A.P. Dias, N. Papageorgiou, K. Kalyanasundaram, M. Grätzel., Inorg. Chem. $1996(35) 1168-1178$.

18. T. Herr, J. Noack, P. Fischer, J. Tübke, Electrochim. Acta 2013 (113) 127-133.

19. A.W. Taylor, S. Puttick, P. Licence, J. Am. Chem. Soc. 2012 (134) 15636-15639.

20. M. Schmeisser, P. Illner, R. Puchta, A. Zahl, R. van Eldik, Chem. Eur. J. 2013 (19) $16835-16836$.

21. J.-F. Gal, C. Laurence, Chem. Eur. J. 2013 (19) 16832-16834. 
22. M. Schmeisser, P. Illner, R. Puchta, A. Zahl, R. van Eldik, Chem. Eur. J. 2012 (18) 10969-10982.

23. R.G. Compton, C.E. Banks, Understanding Voltammetry, Imperial College Press, $2^{\text {nd }}$ Ed., Imperial College Press, London, 2011, p. 244.

24. A.J. Bard, L.R. Faulkner, Electrochemical Methods: Fundamentals and Applications, John Wiley \& Sons, $2^{\text {nd }}$ Ed., John Wiley \& Sons, New York, 2001, p 242.

25. M.C. Buzzeo, R.G. Evans, R.G. Compton, ChemPhysChem 2004 (5) 1106-1120.

26. A. Ejigu, K.R.J. Lovelock, P. Licence, D.A. Walsh, Electrochim. Acta 2011 (56) 1031310320.

27. F. Rahman, M. Skyllas-Kazacos, J. Power Sources 2009 (189) 1212-1219.

28. A.M. O'Mahony, D.S. Silvester, L. Aldous, C. Hardacre, R.G. Compton, J. Chem. Eng. Data 2008 (53) 2884-2891.

29. A.A. Shinkle, A.E.S. Sleightholme, L.D. Griffith, L.T. Thompson, C.W. Monroe, J. Power Sources 2012 (206) 490-496. 

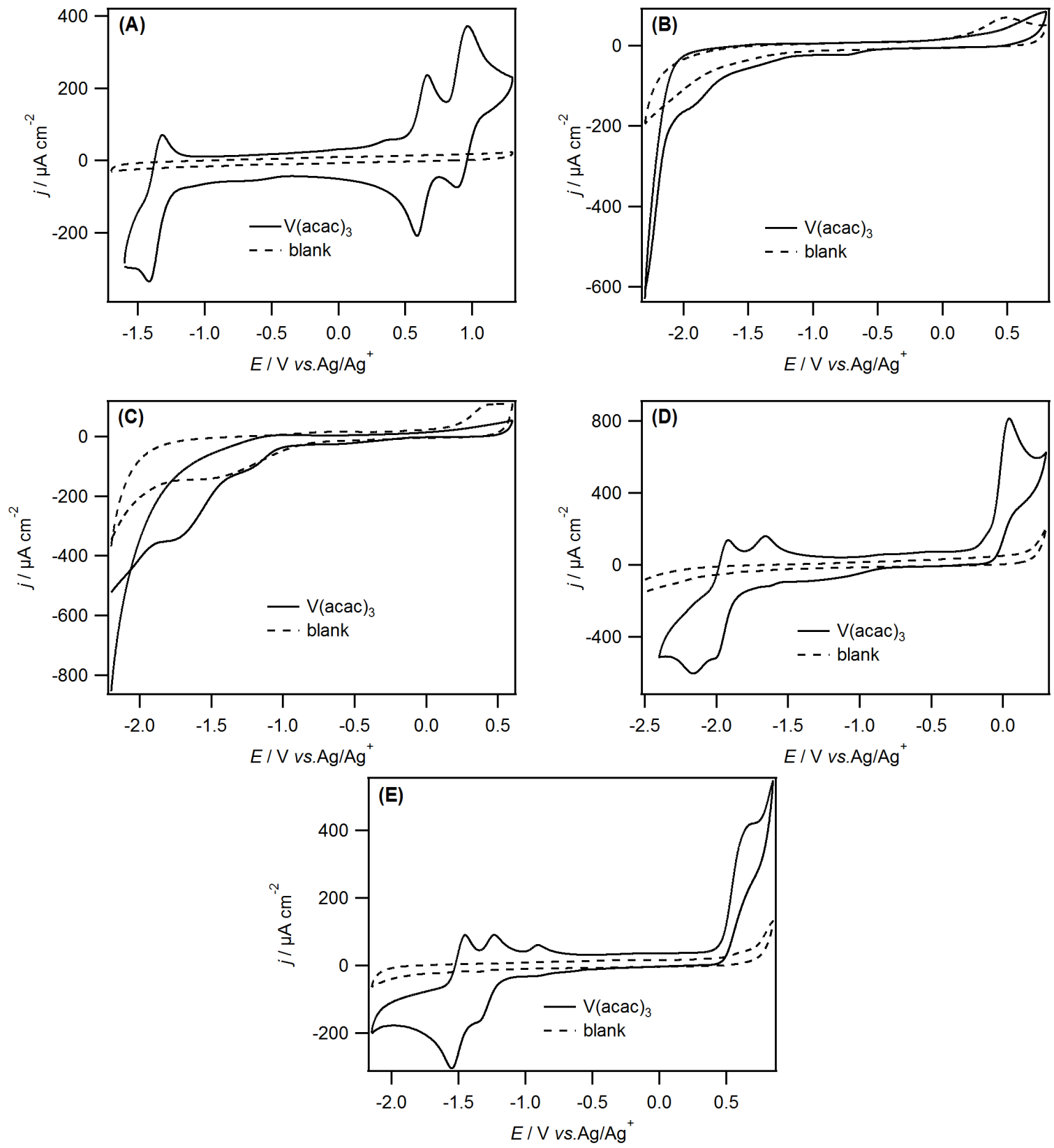

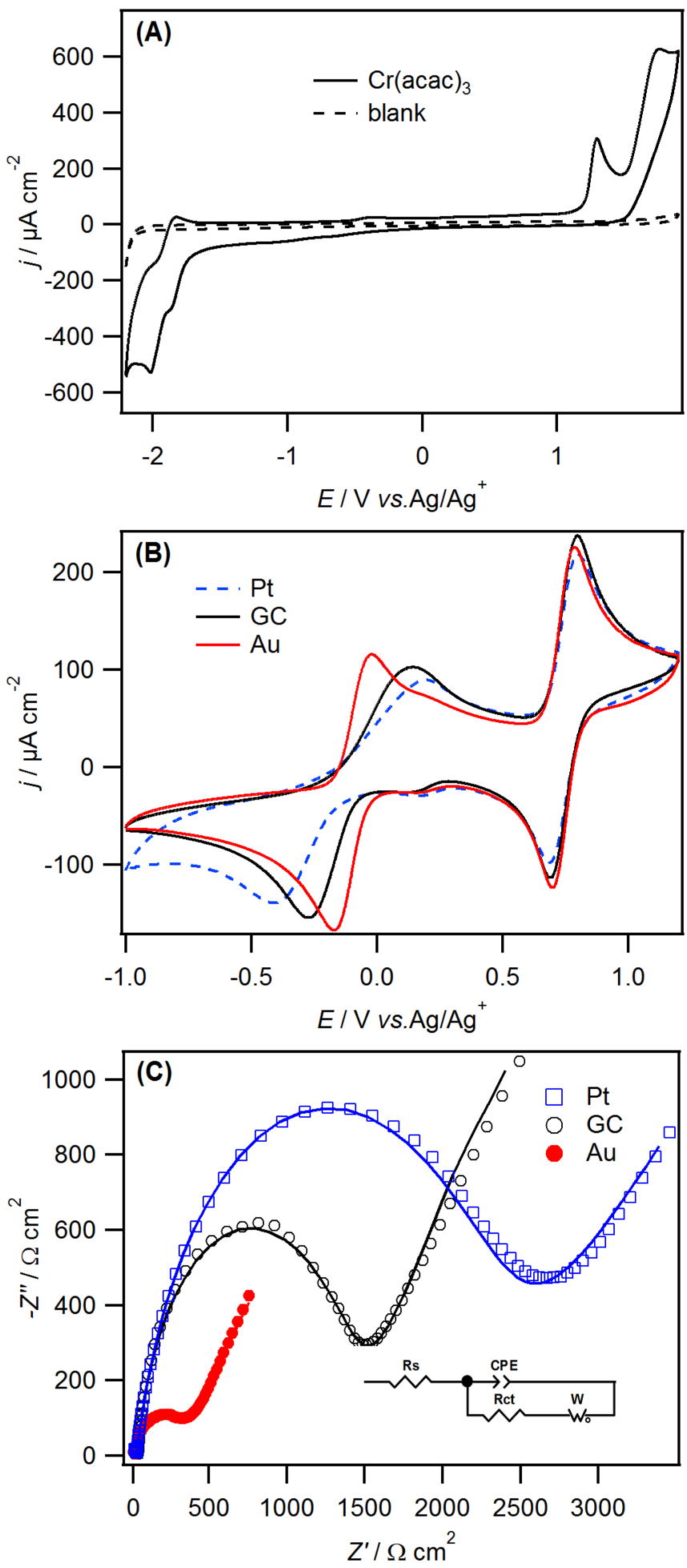

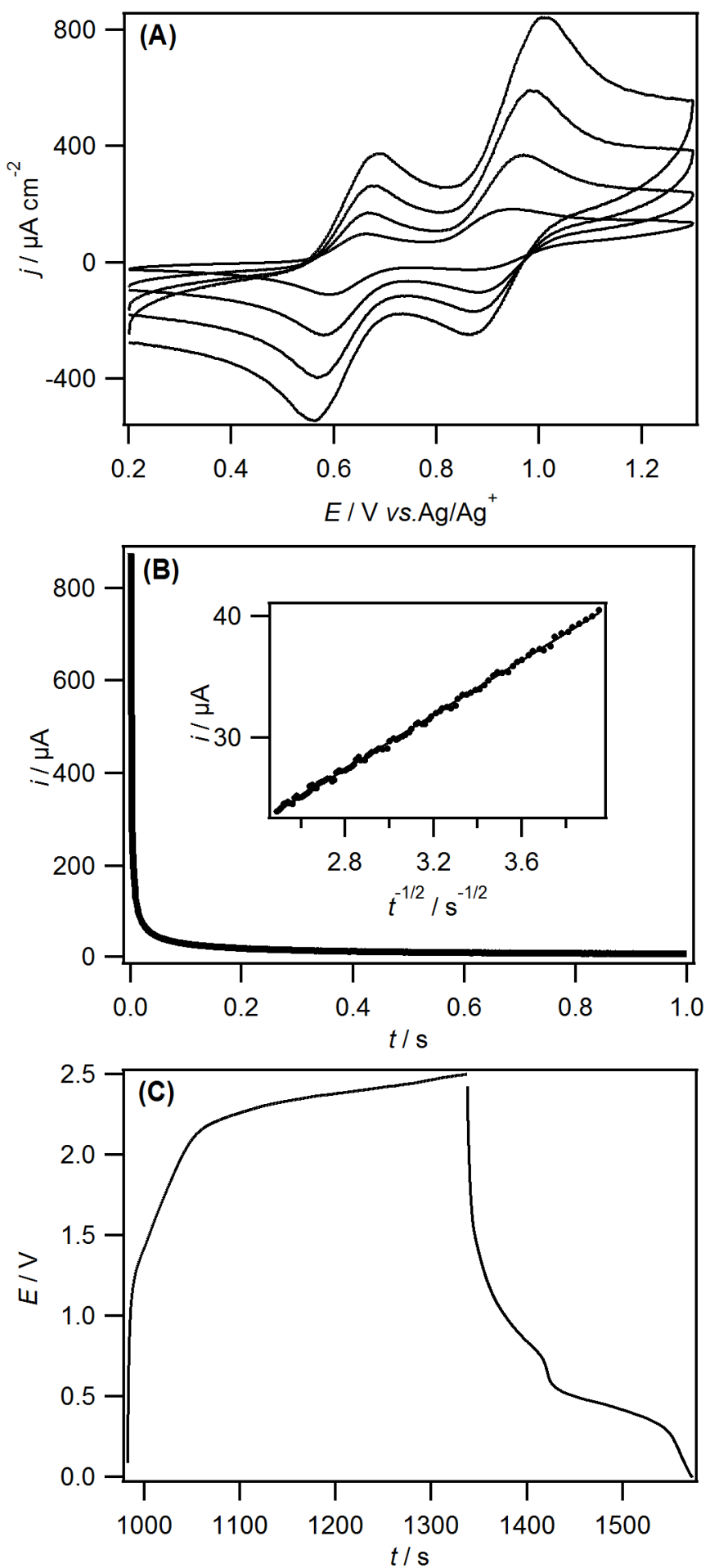